\section{THE FOURTH INTERNATIONAL CONGRESS OF BIOCHEMISTRY}

Proceedings of the Fourth International Congress of Biochemistry

Vienna, I-6 September, 1958. Vols. 1-15. (London and New York: Pergamon Press, 1959-1960.) £48 net complete. (Separate volumes range in price, according to size, from $63 s$. to $100 s$.)

T

HE First International Congress of Biochemistry was organized on the initiative of the Biochemical Society, and was held in Cambridge eleven years ago. There were about 1,700 members and the main publication, apart from a greatly treasured book on Gowland Hopkins, was a volume of abstracts of communications which would almost fit into the pocket. In 1958, the Fourth International Congress was held in Vienna. More than 5,000 attended and the publications of this Congress, now complete, amount to no less than fifteen substantial volumeswell over 4,000 pages in all. It is astonishing that this large bulk of published material should have emanated from the proceedings of a meeting lasting only six days. It is a reminder of the organizing efficiency and hard work of Prof. Hoffmann-Ostenhof (who has also acted as general editor of these volumes) and his colleagues in Vienna, who made it possible for so many communications to be given in so short a time. This meant, of course, that members frequently had to make a choice from among several communications which were being given simultaneously. Now, with the publication of these volumes, they can read what happened at the meetings they had to miss.

The first twelve volumes are devoted to the symposia. It should be stressed that the pre-prints which were made available at the Congress are no substitute for these volumes, which contain revised and much more complete accounts of the meetings. Moreover, they give some account of the discussion which took place. The subjects covered (with volume numbers and editors in parentheses) are the following : (1) carbohydrate chemistry of substances of biological interest (M. L. Wolfrom) ; (2) biochemistry of wood (K. Kratzl and G. Billek); (3) biochemistry of the central nervous system (F. Brücke); (4) steroids (E. Mosettig) ; (5) antibiotics (K. H. Spitzy and R. Brunner); (6) biochemistry of morphogenesis (W. J. Nickerson); (7) biochemistry of viruses (E. Broda and W. Frisch-Niggemeyer); (8) proteins (H. Neurath and H. Tuppy); (9) physical chemistry of high polymers of biological interest (O. Kratky); (10) blood-clotting factors (E. Deutsch); (11) vitamin metabolism (H. Molitor and W. Umbreit); (12) biochemistry of insects (L. Levenbook).

The colloquia, dealing with topical questions in biochemistry, are given in Volume 13. They include: sulphur metabolism (edited by K. S. Dodgson); purine and pyrimidine biosynthesis (odited by $H$. Chantrenne); oxygenating enzymes (edited by $\mathrm{O}$. Hayaishi); metabolism of $\mathrm{C}_{2}$-compounds in microorganisms (edited by Sir Hans Krebs) ; biosynthetic mechanisms in higher plants (edited by P. K. Stumpf); and growth chemistry of bacteria (edited by G. Toennies and E. E. Snell). Volume 14 (edited by W. Auerswald and O. Hoffmann-Ostenhof) contains the transactions of the plenary sessions and includes the invitation lectures of the Congress. Prof. E. Chargaff, of New York, lectured on the chemistry of heredity, and Prof. E. Braunstein, of Moscow, on the chemical integration of nitrogen metabolism. Volume 15 consists of abstracts of the sectional papers together with a subject index of the symposia and colloquia, ranging from 'abietic acid' to 'zymosterol'.

The printing, illustrations and binding of these volumes are of high quality. Presumably, most biochemists will have to look to their librarians rather than to themselves to provide the complete set, but fortunately, individual volumes can be bought separately. Whether congress publication can go on increasing in bulk at its present rate, or even be maintained at its present level, is another matter. It might be argued that the amount of material and the cost of its publication are becoming unmanageably largo and that, in any event, much of the work will be published in more definitive form in the regular journals. However that may be, to those who were there, these volumes will bring back memories of a week of friendly hospitality in beautiful surroundings - memories, not only of scientific discussions, but also of Mozart's 'Magic Flute' at the Vienna State Opera, and of the first sight of Melk Abbey. All biochemists owe a debt to the organizers of this Congress, and to those who worked afterwards to produce this most impressive permanent record of the meeting.

\section{C. Harrison}

\section{PROGRESS IN ALKALOID CHEMISTRY}

The Alkaloids

Chemistry and Physiology. Edited by R. H. F. Manske. Vol. 6 (Supplement to Volumes 1 and 2). Pp. xii +442. 14 dollars. Vol. 7 : Supplement to Volumes 2, 3, 4, and 5. Pp. xiii +558, 17 dollars. (New York: Academic Press, Inc. ; London : Academic Press, Inc. (London), Ltd., 1960.)

THE arrangement of these volumes follows that of the five original volumes of "Manske-Holmes" which appeared during the period 1949-55, and which these are designed to sipplement. The relation of their chapters and sections to the chapters of the original work is carefully detailed, and the numbering in the bibliographies continues from the numbers previously reached. The authorities from Canada, Czechoslovakia, Germany, Hungary, Switzerland, the United Kingdom and the United States are those who contributed the chemical sections of the original, and, like the editor, have lost nothing of their clarity and comprehensive grasp.

The bibliographies may generally be taken to cover as far as 1957, with addenda in one or two cases to 1958. The two volumes may therefore be regarded as an exhaustive review of progress during something less than a decade in alkaloid chernistry.

There is no systematic supplementing of the nine chapters in Volume 5, by specialists on particular pharmacological aspects-among which, even a short time ago, 'tranquillizer' effects found no place-but this omission is to some extent made good by summaries of relevant pharmacological work included in many chapters of the supplement. An attractive example may be noted in section 5 of the chapter on tropane alkaloids, tracing the correlation of mydriatic effects with an esterified $\alpha$-hydroxyl group on $\mathrm{C}(3)$ (as in atropine and hyoscyamine), anæsthetic effects with esters of the stereoisomeric 